\title{
Kombinasi Analytical Hierarchy Process (AHP) dan Data Envelopment Analysis (DEA) untuk Pemilihan Supplier Pada UD. Jepara Putra Mebel
}

\author{
Wilma Latuny" ${ }^{* 1}$, Daniel Bunga Paillin ${ }^{2}$, Samrotul Yaniah ${ }^{3}$ \\ ${ }^{123)}$ Program Studi, Teknik Industri, Universitas Pattimura, Kampus Poka, Ambon, 97233, Indonesia \\ Email: wlatuny@gmail.com ${ }^{1}$,daniel.paillin@ fatek.unpatti.ac.id ${ }^{2}$, samrotuly2018@gmail.com ${ }^{3}$
}

DOI: 10.20961/performa.19.2.46324

\begin{abstract}
Abstrak
Penelitian ini membahas tentang pemilihan supplier bahan baku kayu pada UD. Jepara Putra Mebel dengan integrasi AHP dan DEA. Hasil pengolahan data dengan metode AHP diperoleh nilai bobot prioritas tertinggi adalah supplier A (0.504), supplier B(0.371), supplier $C(0.125)$. Hasil perhitungan dengan metode AHP-DEA untuk mengevaluasi setiap Decision Making Unit (DMU) atau Supplier, diperoleh nilai tingkat efisiensi untuk Supplier A, C memiliki tingkat nilai efisienasi 1, dan supplier $B$ tidak efisien. Hasil AHP-DEA super efisiensi menunjukan supplier C memiliki nilai tertinggi sebesar 2. 095 hasil ini menunjukan bahwa setiap Supplier $C$ dikatakan lebih effisien dari supplier A, sehingga pendekatan AHP-DEA merekomendasikan kepada perusahan untuk Supplier yang harus di utamakan pertama yaitu Supplier C, kemudian kedua Supplier A dan ketiga yaitu Supplier B tentunya melalui pertimbangan kriteria Harga, Kualitas, Pelayanan, Pengiriman, Ketetapan jumlah dan evaluasi tingkat efisiensi setiap DMU yang telah dilakukan.
\end{abstract}

Kata kunci: AHP, DEA, Pemilihan Supplier

\section{Abstract}

This research discusses the selection of supplier of wood raw material at UD. Jepara Putra Mebel using integration of AHP and DEA method. The result shows that in the AHP method, the highest priority weight value is for supplier A (0.504), supplier B (0.371), and supplier $C(0.125)$ respectively. Further, in the AHP-DEA computational result used to evaluate Decision Making Unit (DMU) indicates that efficiency value for supplier $A$ and $C$ is 1 while supplier $B$ is inefficient. In the super efficiency result obtain the highest value 2.095 for supplier $C$, thus it can be infered that supplier $C$ is more efficient than supplier A, therefore AHP-DEA approach recommends that an ultimate supplier company is supplier C, followed by supplier A and supplier B by considering price, quality, service, delivery and evaluation result of DMU.

Keywords: AHP, DEA, Selection Supplier

\section{Pendahuluan}

Pemilihan supplier menjadi bagian yeng terpenting dalam hal penyediaan bahan baku untuk proses produksi suatu perusahaan. Oleh karena itu perusahaan harus dapat memilih dengan tepat supplier yang mampu menjamin kelancaran bahan baku dengan melihat pertimbangan banyak faktor seperti faktor harga dari supplier, faktor kualitas bahan baku, faktor ketepatan jumlah pengiriman, faktor waktu pengirman dan sebagainya (Adriantantri. E, et al, 2020)

UD. Jepara Putra Mebel merupakan perusahan yang memproduksi barang-barang furniture dan memiliki beberapa supplier sebagai penyedia bahan baku dalam proses produksinya. Masalah yang dihadapi UD. Jepara Putra Mebel adalah kedatangan bahan baku yang terlambat yang mengakibatkan proses produksi terganggu, selain itu juga kualitas dan kuantitas bahan

*Corresponding author : wlatuny@gmail.com 
baku kayu ada yang rusak dan tidak sesuai spesifikasi yang dapat mempengaruhi kualitas produk akhir yang dihasilkan. Oleh karena itu diperlukan pemilihan Supplier bahan baku dengan mempertimbangkan beberapa hal yaitu harga, kualitas, pelayanan dan pengiriman.

Pemilihan supplier akan menjadi kompleks ketika munculnya banyak kriteria yang menjadi pertimbangan dalam pemilihan, oleh karena suatu supplier kemungkinan mempunyai kemampuan yang baik pada beberapa kriteria (Darmawan, et al., 2013). Banyak penelitian yang dilakukan dalam pemilihan supplier menggunakan pendekatan yang berbeda. Wulandari (2014) menggunakan metode AHP untuk memilih pemasok spare part mesin industr pada PT. Alfindo dengan menggunakan kriteria harga, kualitas, pelayanan, waktu pengiriman, dan responsibilitas. Lim \& Zhang (2016) dan Adriantantri, et.al (2020) mencoba menggunakan pendekatan AHP dan DEA dalam pemilihan supplier dengan menambahkan faktor resiko. Pada penelitian ini pemilihan supplier menggunakan AHP untuk menentukan keputusan dengan menggunakan kriteria harga, kulaitas, pelayanan, pengiriman dan ketetapan jumlah, yang akan dintgerasikan dengan metode DEA dimana masing-masing pemasok Decision Making Unit (DMU) dinilai efisiensi.

Adapun tujuan dari penelitian ini yaitu mengidentifikasi kriteria-kriteria penting untuk memilih Supplier/pemasok kayu pada UD. Jepara Putra Mebel. Kemudian Memperoleh Supplier/pemasok terbaik yang paling memenuhi kriteria yang sudah di tentukan, dan juga Mengevaluasi tingkat efisiensi dari setiap Supplier.

\section{Metode Penelitian}

\section{Analytical Hierarchy process (AHP)}

Pada tahun 1970 Thomas L. Saaty memperkenalkan suatu metode pengambilan keputusan yang menggabungkan 2 aspek yaitu aspek kualitatif dan kuantitatif untuk pemecahan masalah yang kompleks dan tidak terstruktur kemudian diatur secara hirarki dan diproses secara sistematis. Metode ini umumnya dikenal sebagai metode Analytical Hierarchy Process (Paillin \& Talib, 2013)

Menurut penelitian yang dilakukan oleh Wulandari (2014), AHP dipakai untuk mengusulkan alternative proses seleksi, karena perusahaan selalu memilih pemasok secara subyektif hanya berdasarkan kriteria harga. Kriteria yang digunakan dalam penelitian tersebut adalah harga, kualitas, pelayanan, waktu pengiriman dan responsibilitas. Selanjutnya penelitian serupa tentang pemilihan supplier menggunakan AHP juga dilakukan oleh Darmawan, et al. (2013) menggunakan 5 kriteria yaitu harga, kualitas, delivery performance, garansi dan order fulfillment. Sama dengan penelitian diatas, pada penelitian ini juga melakukan pemilihan supplier dengan AHP namun mencoba menambahkan kriteria kuantitas (ketepatan jumlah) pada pemilihan supplier.

\section{Data Envelopment Analysis (DEA)}

Data Envelopment Analysis adalah metode pengambilan keputusan yang tepat untuk menilai efisensi dari supplier. DEA digunakan untuk mengukur efisensi relative dari Decision Making Unit (DMU) untuk masing-masing supplier dengan kriteria input-output secara keseluruhan (Lim \& Zhang., 2016).

Efisiensi didefenisikan sebagai ratio antara bobot output terhadap bobot input. Secara umum ratio efisensi untuk DMU adalah sebagai berikut (Hasan, et al, 2008) dan (Cook \& Seiford, 2009) :

$$
E_{a b}=\frac{\sum_{y} O_{b y} v_{a y}}{\sum_{x} I_{b x} u_{a x}}
$$


Dimana :

$E_{a b}$ adalah efisensi dari DMu $b$, menggunakan bobot 'test' DMU a

$O_{b y}$ adalah output $y$ dari DMU $b$

$v_{a y}$ adalah bobot untuk 'test' DMU $a$ duntuk output $y$

$I_{b x}$ adalah input $x$ dari DMU $b$

$U_{a x}$ adalah bobot untuk 'test' DMU $a$ untuk input $x$

Model dasar DEA pertama kali diperkenalkan oleh Charnes, Cooper dan Rhodes pada tahun 1978 (Charnes, et al, 1978). Juga lebih dikenak dengan model CCR dasar, formulasi dari model untuk DMU adalah sebagai berikut :

$$
\max E_{a a}=\frac{\sum_{y} O_{a y} v_{a y}}{\sum_{x} I_{a x} u_{a x}}
$$

Dengan batasan

$$
\begin{aligned}
& E_{a b} \leq 1 \quad \forall b \\
& u_{a x}, v_{a y} \geq 0
\end{aligned}
$$

di mana $E_{a b}$ sama dengan istilah dalam persamaan (1). Variabel keputusan model (2) adalah $u_{\mathrm{ax}}$ dan $v_{a y}$. Model nonlinier diatas kemudian diubah kedalam bentuk liniear programming untuk lebih memudahkan perhitungan dan lebih dikenal sebagai model DEA CCR Primal :

$$
\max \sum_{y} O_{a y} v_{a y}
$$

Dengan batasan :

$$
\begin{aligned}
& \sum_{y} O_{b y} v_{a y} \leq \sum_{x} I_{b x} u_{a x} \quad \forall b \\
& \sum_{x} I_{a x} u_{a x}=1 \\
& u_{a x}, v_{a y} \geq 0
\end{aligned}
$$

Nilai efisiensi optimal diperoleh dari Model CCR paling banyak sama dengan 1 (Ramanathan, 2007), menunjukan bahwa ada kemungkinan beberapa DMU mungkin memiliki nilai maksimum yang sama dengan 1 . Hal ini terjadi ketika DMU ini terletak pada batas optimal dan tidak didominasi oleh DMU lain. Pembuat keputusan akan sulit untuk menentukan peringkat darii DMU yang paling efisien.

Untuk mengatasi hal diatas, dilakukan pengembangan dari model CCR dasar dan dikenal sebagai model super-efisensi CCR, yang diusulkan olej Andersen dan Peterson pada tahun 1993.

$$
\max \sum_{y} O_{a y} v_{a y}
$$

Dengan batasan :

$$
\begin{aligned}
& \sum_{y} O_{b y} v_{a y} \leq \sum_{x} I_{b x} u_{a x} \quad \forall b, b \neq a \\
& \sum_{x} I_{a x} u_{a x}=1 \\
& u_{a x}, v_{a y} \geq 0
\end{aligned}
$$

Pada penelitian ini kriteria harga menjadi viriabel output dan variable input adalah kriteria kualitas, pelayanan, pengiriman dan ketepatan jumlah. Flowchart berikut ini menunjukan adalah tahapan penelitian: 


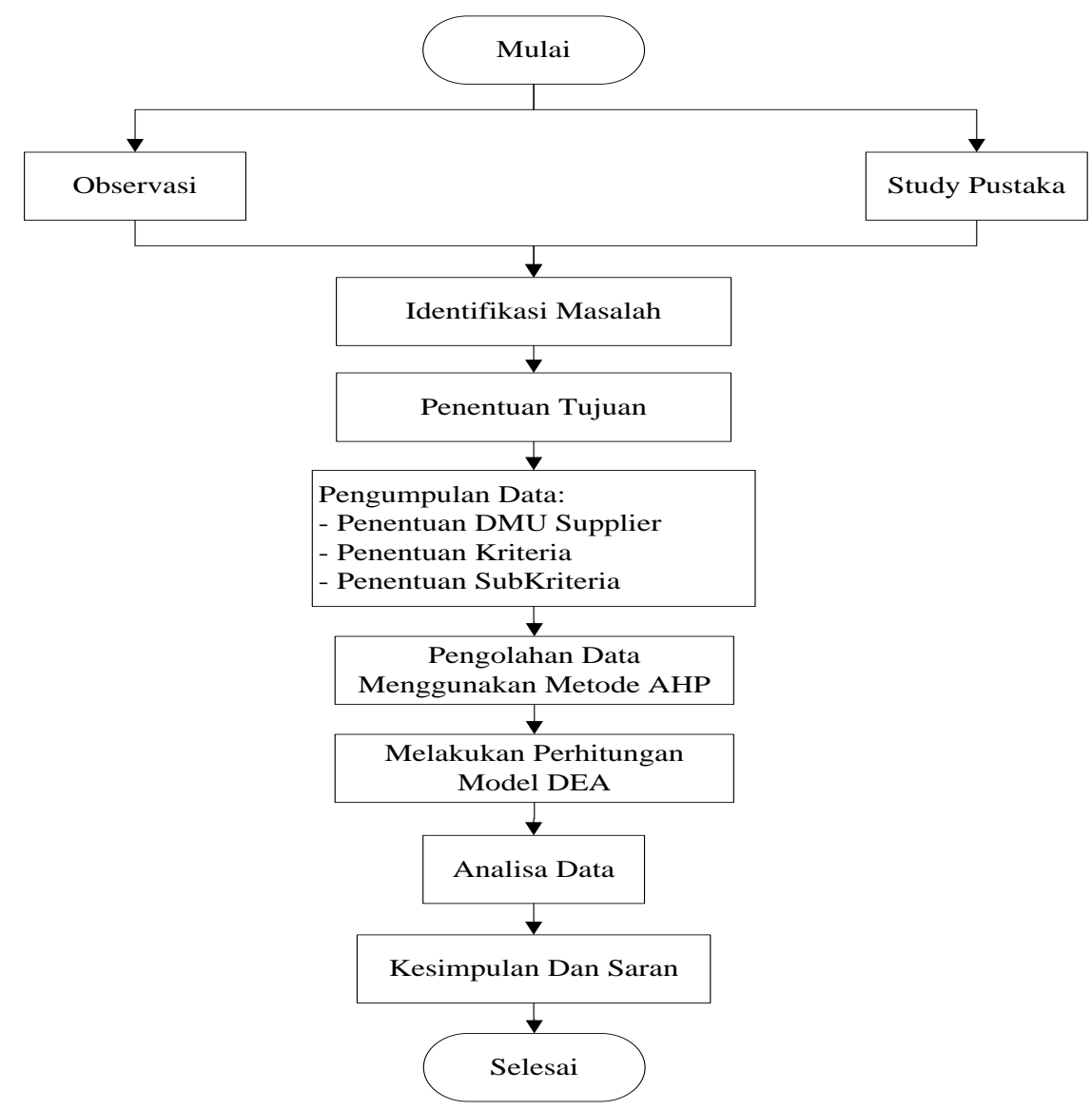

Gambar 1.Flowchart Penelitian

\section{Hasil dan Pembahasan}

\section{Struktur Hirarki}

Struktur hirarki dari UD. Jepara Putra MEbel disusun dalam 3 level yang ditunjukan pada gambar 2 sebagai berikut:

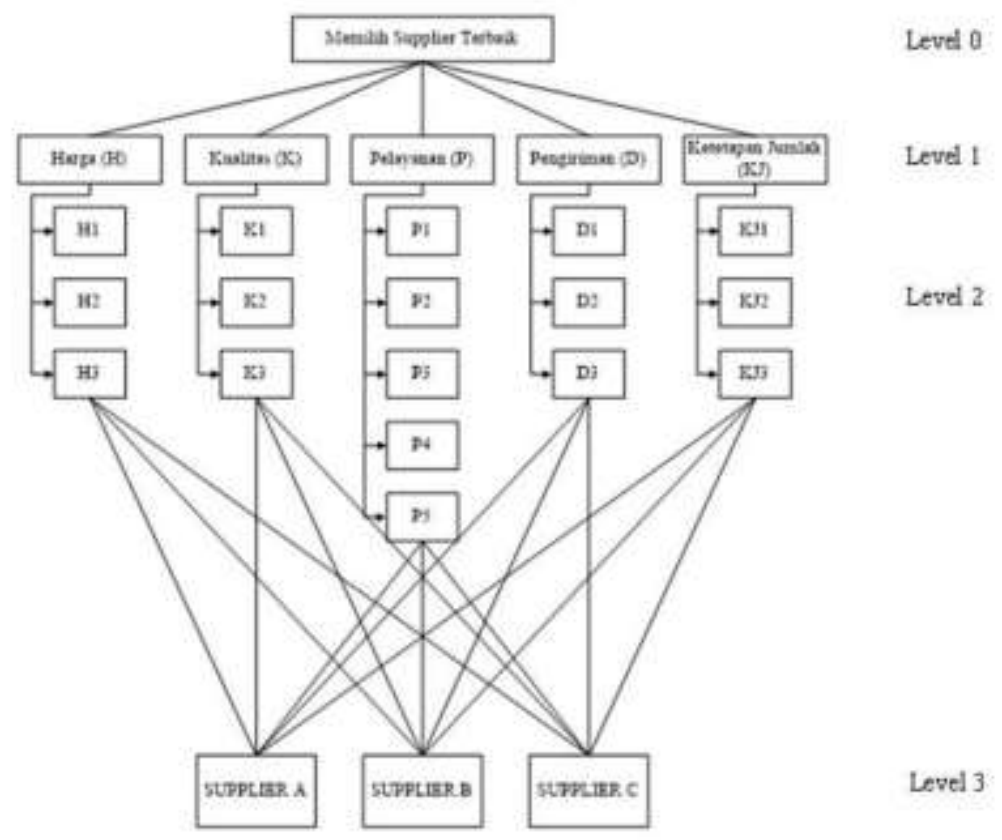

Gambar 2.Struktur Hirarki Keputusan Pemilihan Supplier UD. Jepara Putra Mebel Sumber Thomas L. Saaty, 1994 (di modifikasi) 


\section{Pembobotan mengguankan Metode AHP}

Tabel 1 berikut ini merupakan penilian kriteria untuk matriks perbandingan berpasangan dari masing-masing responden yang nilai rata-ranya menggunakan geometric mean, yang kemudian diolah menggunakan software expert choice untuk mendapatkan bobot masingmasing kriteria sebagai berikut:

Tabel 1 Perbandingan Berpasangan Antar Kriteria

\begin{tabular}{|l|c|c|c|c|c|}
\hline \multicolumn{1}{|c|}{ Kriteria } & Harga & Kualitas & $\begin{array}{c}\text { Pelayana } \\
\mathbf{n}\end{array}$ & $\begin{array}{c}\text { Pengirima } \\
\mathbf{n}\end{array}$ & $\begin{array}{c}\text { Ketetapan } \\
\text { Jumlah }\end{array}$ \\
\hline Harga & 1,00 & 1,00 & 1,00 & 5,00 & 1,00 \\
\hline Kualitas & 1,00 & 1,00 & 1,00 & 4,00 & 2,00 \\
\hline Pelayanan & 1,00 & 1,00 & 1,00 & 3,00 & 2,00 \\
\hline Pengiriman & 0,20 & 0,25 & 0,33 & 1,00 & 1,00 \\
\hline $\begin{array}{l}\text { Ketetapan } \\
\text { Jumlah }\end{array}$ & 1,00 & 0,50 & 0,50 & 1,00 & 1,00 \\
\hline
\end{tabular}

Berikut ini adalah salah satu contoh hasil pembobotan dari pengolahan menggunakan software expert choice untuk masing-masing kriteria

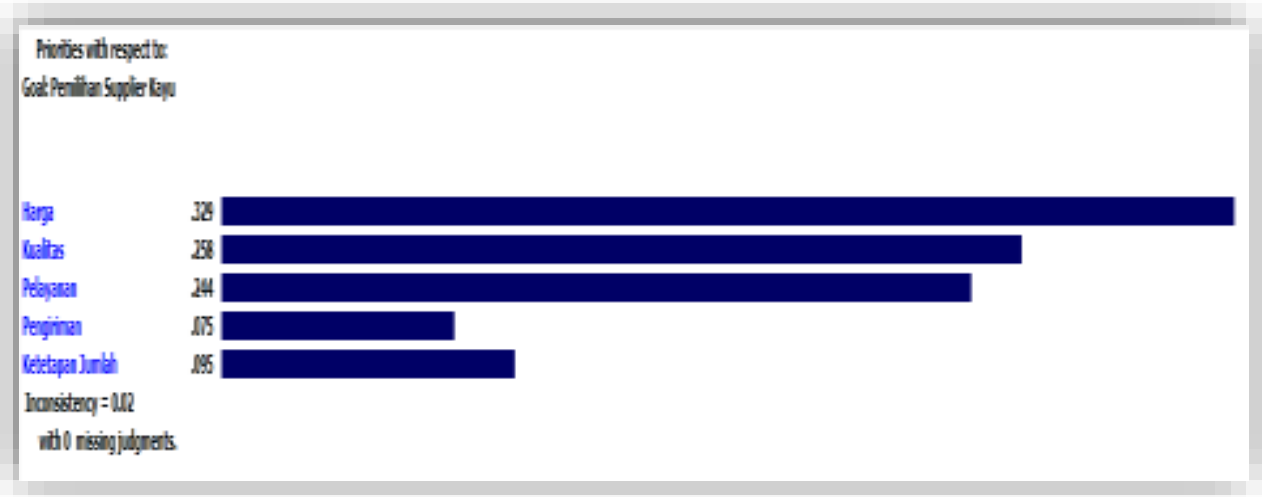

Gambar 3. Hasil Pembobotan dan Uji konsistensi Kriteria

Secara keseluruhan untuk hasil perhitungan pembobotan untuk masing-masing kriteria dan subkriteria menggunakan software expert choice ditunjukan pada tabel 2 berikut ini.

Tabel 2 Bobot Kriteria Dan Subkriteria (hasil perhitungan dengan software expert choice)

\begin{tabular}{|c|c|c|c|c|c|}
\hline Kriteria & $\begin{array}{c}\text { CR } \\
\text { Antar } \\
\text { Kriteria }\end{array}$ & Bobot & $\begin{array}{l}\text { CR Antar } \\
\text { Kriteria dan } \\
\text { Sub kriteria }\end{array}$ & Subkriteria & Bobot \\
\hline \multirow{3}{*}{$\operatorname{Harga}(\mathrm{H})$} & \multirow{10}{*}{0,02} & \multirow{3}{*}{0,329} & \multirow{3}{*}{0,08} & H1 & 0,627 \\
\hline & & & & $\mathrm{H} 2$ & 0,280 \\
\hline & & & & $\mathrm{H} 3$ & 0,094 \\
\hline \multirow{3}{*}{ Kualitas (K) } & & \multirow{3}{*}{0,258} & \multirow{3}{*}{0,05} & K1 & 0,474 \\
\hline & & & & $\mathrm{K} 2$ & 0,376 \\
\hline & & & & K3 & 0,149 \\
\hline \multirow{4}{*}{ Pelayanan $(\mathrm{P})$} & & \multirow{4}{*}{0,244} & \multirow{4}{*}{0,01} & $\mathrm{P} 1$ & 0,209 \\
\hline & & & & $\mathrm{P} 2$ & 0,310 \\
\hline & & & & $\mathrm{P} 3$ & 0,219 \\
\hline & & & & $\mathrm{P} 4$ & 0,137 \\
\hline
\end{tabular}




\begin{tabular}{|c|c|c|c|c|}
\hline & & & P5 & 0,125 \\
\hline \multirow{3}{*}{ Pengiriman (D) } & \multirow{3}{*}{0,075} & \multirow{3}{*}{0,03} & D1 & 0,209 \\
\hline & & & D2 & 0,156 \\
\hline & & & D3 & 0,185 \\
\hline \multirow{3}{*}{$\begin{array}{l}\text { Ketetapan } \\
\text { Jumlah (KJ) }\end{array}$} & \multirow{3}{*}{0,095} & \multirow{3}{*}{0,03} & KJ1 & 0,481 \\
\hline & & & $\mathrm{KJ} 2$ & 0,405 \\
\hline & & & KJ3 & 0,114 \\
\hline
\end{tabular}

Gambar di berikut menunjukkan bahwa secara keseluruhan, Supplier A dengan nilai bobot $(0,504)$ merupakan prioritas pertama untuk dipilih sebagai Supplier kayu pada UD Jepara Putra Mebel. Prioritas kedua adalah Supplier B dengan nilai bobot $(0,371)$, sedangkan prioritas terakhir adalah Supplier C dengan nilai bobot $(0,125)$

\section{Syrthesis with respect tox Gost Pemillihan Suppler Kayu}

\section{Overal Inconsidetency $=.05$}

SUPPLIERA .504

SUPPLIER B .371

SUPPLIERC .125

Gambar 4. Prioritas Penentuan Supplier terpilihpada UD Jepara Putra Mebel.

\section{Model DEA}

Tabel 3 berikut merupakan data sekunder yang didapat pada perusahaan yang akan digunakan model DEA.

Tabel 3 Data Sekunder Perusahaan

\begin{tabular}{|l|c|c|c|c|c|}
\hline Suplier & $\begin{array}{c}\text { Harga } \\
\left(\mathbf{R p} / \mathbf{m}^{\mathbf{3}}\right)\end{array}$ & Kualitas & $\begin{array}{c}\text { Pelayanan } \\
(\mathbf{J a m})\end{array}$ & $\begin{array}{c}\text { Pengiriman } \\
(\mathbf{M i n g g u})\end{array}$ & $\begin{array}{c}\text { Ketepatan Jumlah } \\
\left(\mathbf{m}^{\mathbf{3}}\right)\end{array}$ \\
\hline $\mathrm{A}$ & 6.000 .000 & 3 & 2 & 1 & 10 \\
\hline $\mathrm{B}$ & 5.500 .000 & 2 & 1 & 1 & 10 \\
\hline $\mathrm{C}$ & 5.250 .000 & 2 & 1 & 2 & 10 \\
\hline
\end{tabular}

DMU yang akan dianalisa efisiensinya berjumlah 3 DMU yaitu supplier A, supplier B, dan supplier C. Gambar di bawah ini menunjukan model keputusan DEA untuk mencari efisensi tiap DMU.

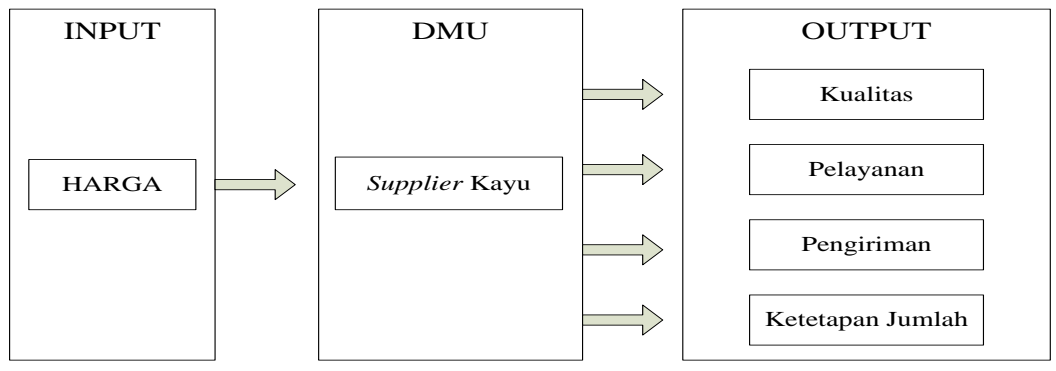

Gambar 5. Model keputusan DEA

Tabel berikut ini merupakan variable output-input yang telah diproses dengan pembobotan AHP untuk digunakan dalam perhitungan pada model DEA. 
Tabel 4 Pembobotan Varibel Input dan Output pada DEA

\begin{tabular}{|l|c|c|c|c|c|}
\hline DMU & $\begin{array}{c}\text { Harga } \\
\left(\boldsymbol{I}_{\boldsymbol{1}}\right)\end{array}$ & $\begin{array}{c}\text { Kualitas } \\
\left(\boldsymbol{O}_{\boldsymbol{1}}\right)\end{array}$ & $\begin{array}{c}\text { Pelayanan } \\
\left(\boldsymbol{O}_{\boldsymbol{2}}\right)\end{array}$ & $\begin{array}{c}\text { Pengiriman } \\
\left(\boldsymbol{O}_{\boldsymbol{3}}\right)\end{array}$ & $\begin{array}{c}\text { Ketepatan Jumlah } \\
\left(\boldsymbol{O}_{\boldsymbol{4}}\right)\end{array}$ \\
\hline 1 & 1974000 & 0.774 & 0.488 & 0.075 & 0.95 \\
\hline 2 & 1809500 & 0.516 & 0.244 & 0.075 & 0.95 \\
\hline 3 & 1727250 & 0.516 & 0.244 & 0.15 & 0.95 \\
\hline
\end{tabular}

Model Matematis DEA Primal CCR-DMU 1:

Fungsi tujuan

$$
\operatorname{Max} E_{1}=0.774 O_{1}+0.488 O_{2}+0.075 O_{3}+0.954 O_{4}
$$

Kendala

$$
\begin{aligned}
& \left(0.774 O_{1}+0.488 O_{2}+0.075 O_{3}+0.954 O_{4}\right)-\left(1974000 I_{1}\right) \leq 0 \\
& \left(0.516 O_{1}+0.244 O_{2}+0.075 O_{3}+0.954 O_{4}\right)-\left(1809500 I_{1}\right) \leq 0 \\
& \left(0.516 O_{1}+0.244 O_{2}+0.15 O_{3}+0.954 O_{4}\right)-\left(1727250 I_{1}\right) \leq 0 \\
& 1974000 I_{1}=1 \\
& I_{l} \geq 0 \\
& O_{1}, O_{2}, O_{3}, O_{4} \geq 0
\end{aligned}
$$

Model Matematis DEA Primal CCR-DMU 2:

Fungsi tujuan

$$
\text { Kendala }
$$

$$
\operatorname{Max} E_{2}=0.516 O_{1}+0.244 O_{2}+0.075 O_{3}+0.954 O_{4}
$$

$$
\begin{aligned}
& \left(0.774 O_{1}+0.488 O_{2}+0.075 O_{3}+0.954 O_{4}\right)-\left(1974000 I_{1}\right) \leq 0 \\
& \left(0.516 O_{1}+0.244 O_{2}+0.075 O_{3}+0.954 O_{4}\right)-\left(1809500 I_{1}\right) \leq 0 \\
& \left(0.516 O_{1}+0.244 O_{2}+0.15 O_{3}+0.954 O_{4}\right)-\left(1727250 I_{l}\right) \leq 0 \\
& 1809500 I_{1}=1 \\
& I_{1} \geq 0 \\
& O_{1}, O_{2}, O_{3}, O_{4} \geq 0
\end{aligned}
$$

Model Matematis DEA Primal CCR-DMU 3:

Fungsi tujuan

Kendala

$$
\operatorname{Max} E_{1}=0.516 O_{1}+0.244 O_{2}+0.15 O_{3}+0.954 O_{4}
$$

$$
\begin{aligned}
& \left(0.774 O_{1}+0.488 O_{2}+0.075 O_{3}+0.954 O_{4}\right)-\left(1974000 I_{1}\right) \leq 0 \\
& \left(0.516 O_{1}+0.244 O_{2}+0.075 O_{3}+0.954 O_{4}\right)-\left(1809500 I_{1}\right) \leq 0 \\
& \left(0.516 O_{1}+0.244 O_{2}+0.15 O_{3}+0.954 O_{4}\right)-\left(1727250 I_{l}\right) \leq 0 \\
& 1727250 I_{1}=1 \\
& I_{1} \geq 0 \\
& O_{1}, O_{2}, O_{3}, O_{4} \geq 0
\end{aligned}
$$

Banyaknya variable dan iterasi yang berulang-ulang maka model diatas akan diolah menggunakan software DEA-Solver 8.0 yang ditunjukan pada tabel 5 berikut ini.

Tabel 5 Hasil Output Efisiensi Tiap DMU

\begin{tabular}{|l|l|l|l|l|l|l|l|l|}
\hline No. & DMU & Score & Rank & $\mathrm{v}(1)$ & $\mathrm{u}(1)$ & $\mathrm{u}(2)$ & $\mathrm{u}(3)$ & $\mathrm{u}(4)$ \\
\hline 1 & 1 & 1 & 1 & $5.07 \mathrm{E}-07$ & 0.484496 & 0 & 0 & 0.657895 \\
\hline 2 & 2 & 0.9545 & 3 & $5.53 \mathrm{E}-07$ & 0 & 0 & 0 & 1.004785 \\
\hline 3 & 3 & 1 & 1 & $5.79 \mathrm{E}-07$ & 0 & 0 & 0 & 1.052632 \\
\hline
\end{tabular}

Tabel diatas memperlihatkan bahwa DMU 1 dan 3 mempunyai nilai efisiensi sebesar 1 yang berarti bawha kedua DMU tersebut efisien. Sedangkan DMU 2 memiliki nila efisiensi 
dibawah 1 sebesar 0.9545 yang artinya tidak efisien. Selanjutnya adalah menentukan ranking dari tiap DMU karena DMU 1 dan 3 mempunyai nilai efisiensi yang sama sehingga perlu dilakukan pengujian super-efisiensi.

Model matematis DEA CCR super-efisiensi DMU 1

Fungsi tujuan

Kendala

$$
\operatorname{Max} E_{l}=0.774 O_{1}+0.488 O_{2}+0.075 O_{3}+0.954 O_{4}
$$

$$
\begin{aligned}
& \left(0.516 O_{1}+0.244 O_{2}+0.075 O_{3}+0.954 O_{4}\right)-\left(1809500 I_{l}\right) \leq 0 \\
& \left(0.516 O_{1}+0.244 O_{2}+0.15 O_{3}+0.954 O_{4}\right)-\left(1727250 I_{1}\right) \leq 0 \\
& 1974000 I_{1}=1 \\
& I_{l} \geq 0 \\
& O_{1}, O_{2}, O_{3}, O_{4} \geq 0
\end{aligned}
$$

Model matematis DEA CCR super-efisiensi DMU 3

Fungsi tujuan

$$
\operatorname{Max} E_{1}=0.516 O_{1}+0.244 O_{2}+0.15 O_{3}+0.954 O_{4}
$$

Kendala

$$
\begin{aligned}
& \left(0.774 O_{1}+0.488 O_{2}+0.075 O_{3}+0.954 O_{4}\right)-\left(1974000 I_{1}\right) \leq 0 \\
& \left(0.516 O_{1}+0.244 O_{2}+0.075 O_{3}+0.954 O_{4}\right)-\left(1809500 I_{1}\right) \leq 0 \\
& \left(0.516 O_{1}+0.244 O_{2}+0.15 O_{3}+0.954 O_{4}\right)-\left(1727250 I_{1}\right) \leq 0 \\
& 1727250 I_{1}=1 \\
& I_{1} \geq 0 \\
& O_{1}, O_{2}, O_{3}, O_{4} \geq 0
\end{aligned}
$$

Model superefisensi diatas dioleh menggunakan software DEA-Solver 8.0 yang ditunjukan pada tabel 6 berikut ini.

Tabel 6 Hasil Output Super Efisiensi Tiap DMU

\begin{tabular}{|r|r|l|l|}
\hline No. & DMU & Score & Rank \\
\hline 1 & 1 & 1.75 & 2 \\
\hline 2 & 2 & 0.9545455 & 3 \\
\hline 3 & 3 & 2.0952381 & 1 \\
\hline
\end{tabular}

Dari hasil super efisiensi diatas menunjukan DMU 3 memiliki nilai super efisiensi yang terbesar kemudian diikuti oleh DMU 1 dan DMU 2.

\section{Perbandingan Hasil dari Tiga Pendekatan}

Tabel 7 berikut menunjukan perbadingan hasil dari 3 pendekatan.

Tabel 7 Perbandingan Hasil dari 3 Pendekatan

\begin{tabular}{|c|c|c|c|}
\hline Suplier & AHP & AHP-DEA CCR & AHP-DEA CCR Super Efisiensi \\
\hline Suplier A & 0.504 & 1 & 1.75 \\
\hline Suplier B & 0.371 & 0.9545 & 0.94545 \\
\hline Suplier C & 0.125 & 1 & 2.095 \\
\hline
\end{tabular}

Hasil pada tabel diatas menunjukan bawa supplier A memiliki nilai prioritas yang besar untuk dipilih sebagai pemasok dengan nilai sebesar 0.504 dan yang paling kecil adalah supplier $\mathrm{C}$ dengan nilai prioritas sebesar 0.125 , akan tetapi pada hasil integrasi AHP-DEA CCR telihat bahwa supplier 1 dan 3 memiliki nilai efisiensi sama yaitu sebesar 1 sedangkan supplier B itu tidak efisien. Karena terdapat 2 suplier yang memilihi nilai efiensi yang sama dilakukan dengan pendekatan AHP-DEA CCR Super-Efisiensi memperlihatkan bahwa Supplier C memiliki nilai yang lebih besar dibandingkan dengan Supplier A. Penelitian ini memperlihatkan bahwa 
supplier yang mempunyai nilai prioritas terbaik pada AHP belum tentu akan terpilih, sehingga menjadi bahan alternative pertimbangan untuk pengambil keputusan dalam memilih supplier yang lebih tepat.

\section{Simpulan}

Berdasarkan pengolahan data yang dilakukan untuk penentuan pemilihan Supplier terbaik pembelian bahan baku dengan menggunakan integrasi AHP dan DEA maka diperoleh hasil yaitu:

1. Hasil pengolahan data dengan metode AHP dapat diperoleh lima kriteria dengan tingkat kepentingan secara berurutan yaitu kriteria harga menjadi prioritas pertama dalam pemilihan Supplier ini dengan bobot nilai $(0,329)$, kemudian kriteria berikutnya yaitu kualitas dengan bobot $(0,258)$, prioritas kriteria ketiga yaitu pelayanan mempunyai bobot kriteria $(0,244)$, dan yang keempat kriteria ketetapan jumah dengan bobot $(0,095)$ kemudian prioritas terakhir yaitu kriteria pengiriman dengan bobot $(0,075)$.

2. Kemudian dengan AHP pula diperoleh bahwa Supplier yang direkomendasikan untuk diprioritaskan dengan memperhatikan kriteria-kriteria diatas adalah Supplier terpilih pertama yaitu Supplier A dengan bobot prioritas $(0,504)$ kemudian urutan prioritas kedua Supplier B dengan bobot $(0,371)$ dan prioritas ketiga yaitu Supplier C dengan bobot $(0,125)$.

Hasil perhitungan dengan AHP-DEA CCR untuk mengevaluasi setiap Decision Making Unit (DMU) atau dalam hal ini setiap Supplier, diperoleh nilai tingkat efisiensi untuk Supplier A dengan tingkat nilai efisienasi 1, Supplier B dengan tingkat nilai efisiensi 0.9545 dan Supplier $\mathrm{C}$ dengan tingkat nilai efisiensi 1 hasil yang didapat ini menunjukan bahwa setiap Supplier/DMUnya dikatakan Efisien karena mencapai nilai efisiensi maksimum. Hasil perhitungan dengan AHP-DEA CCR Super-efisiensi menunjukan supplier C memilikini nilai yang terbesar dibandingkan supplier A yaitu sebesar 2.095. Sehingga berdasarkan kombinasi kedua metode AHP dan DEA merekomendasikan kepada perusahaan untuk Supplier yang harus di utamakan pertama yaitu Supplier C, kemudian kedua Supplier A dan ketiga yaitu Supplier B tentunya melalui pertimbangan kriteria Harga, Kualitas, Pelayanan, Pengiriman, Ketetapan jumlah dan evaluasi tingkat efisiensi setiap DMU yang telah dilakukan.

\section{Daftar Pustaka}

Adriantantri, E., Basuki, D. W. L., \& Nurcahyo, (2020) . Integration of AHP and DEA Methods for Supplier Selection. International Journal of Latest Engineering and Management Research (IJLEMR) Volume 05 - No. 02. pp. 40-47. www.ijlemr.com

Charnes, A.,Cooper, W.W., and Rhodes, E., (1978)., Measuring the efficiency of decision making units. European Journal of Operational Research, vol. 2. No. 6., pp. 429 - 444.

Cook, W. D, and Seiford, L. M.,(2009). Data Envelopment Analysis (DEA) - Thirty years on. European Journal of Operational Research., Vol. 192, No 1., pp. 1 - 17.

Darmawan, H., Setiawan, H. dan Sirajuddin., (2013). Pemilihan Pemasok Bahan Baku Produksi Menggunakan Metode Data Envelopment Analysis. Jurnal Teknik Industri, Vol. 1 No. 2., hal. 157-162

Hasan, M. A., Shankar, R., Sarkis, J., (2008). Supplier Selection in an Agile Manufacturing Environment using Data Envelopment Analysis and Analytical Network Process., International Journal of Logistics Systems and Management, vol. 4, No. 5., pp. 523 550.

Lim,J. J., and Zhang, A.N. (2016). A DEA approach for Supplier Selection with AHP and risk consideration., 2016 IEEE International Conference on Big Data. pp. 3749-3758. 
Paillin, D. B., Talib, T., (2013). Alternatif Penanggulangan Tengkulak Dalam Usaha Budidaya Rumput Laut di Kabupaten Seram Bagian Barat. Jurnal ARIKA., Vol. 07, No. 1., pp. 65-80

Ramanathan,R., (2007)., Supplier selection problem: integrating DEA with the approaches of total cost of ownership and AHP., Supply Chain Management: An International Journal, vol. 12, No. 4., pp. 258 - 261.

Wulandari, N. (2014). Perancangan Sistem Pendukung Keputusan Pemilihan Supplier di PT. Alfindo Dengan Metode Analytical Hierarchy Process (AHP). Jurnal Sistem Informasi,. Vol. 1, No. 1., pp. 4-7 